\title{
The Effect of Lipoic Acid on Antioxidant Status and Lipid Peroxidation in Rats Exposed to Chronic Restraint Stress
}

\author{
D. AKPINAR ${ }^{1}$, P. YARGIÇOĞLU ${ }^{1}$, N. DERIN ${ }^{1}$, Y. ALICIGÜZEL ${ }^{2}$, A. AĞAR ${ }^{3}$ \\ ${ }^{1}$ Akdeniz University, Faculty of Medicine, Department of Biophysics, ${ }^{2}$ Department of Biochemistry \\ and ${ }^{3}$ Department of Physiology, Arapsuyu, Antalya, Turkey
}

Received May 8, 2007

Accepted September 26, 2007

On-line November 30, 2007

\section{Summary}

This study was designed to investigate effect of alpha-lipoic acid (LA) on lipid peroxidation, nitric oxide production and antioxidant systems in rats exposed to chronic restraint stress. Twenty four male Wistar rats, aged three months, were divided into four groups: control (C), the group treated with LA (L), the group exposed to restraint stress (S) and the group exposed to stress and treated with LA (LS). Restraint stress was applied for 21 days ( $1 \mathrm{~h} /$ day) and LA (100 mg/kg/day) was injected intraperitonally to the $L$ and $L S$ groups for the same period. Restraint stress significantly decreased brain copper/zinc superoxide dismutase $(\mathrm{Cu}, \mathrm{Zn}-\mathrm{SOD})$ and brain and retina glutathione peroxidase (GSH$\mathrm{Px}$ ) and catalase (CAT) activities compared with the control group. Thiobarbituric acid reactive substances (TBARS), nitrite and nitrate levels were significantly increased in the tissues of the $\mathrm{S}$ group compared with the $\mathrm{C}$ group. LA produced $\mathrm{a}$ significant decrease in brain and retina TBARS, nitrite and nitrate levels of the $L$ and $L S$ groups compared to their corresponding control groups. LA increased all enzyme activities in the tissues of the LS group compared to the $S$ group. Our study indicated that LA is an ideal antioxidant candidate for the prevention of stressinduced lipid peroxidation.

\section{Key words}

Restraint stress • Lipoic acid • Lipid peroxidation • Antioxidant enzymes

\section{Corresponding author}

P. Yargıçoğlu, Department of Biophysics, Faculty of Medicine, Akdeniz University, Arapsuyu, 07070 Antalya, Turkey. Fax: 0 090242-2274495. E-mail: pakkiraz@akdeniz.edu.tr

\section{Introduction}

Stress is conceived as an aversive stimulus capable of altering physiological homeostasis, and the ability to cope with such stressful stimuli is a crucial determinant of health and disease (Masood et al. 2003). Intensive stress has detrimental effects on organism by causing cellular and tissue injury. The mechanisms underlying stress-induced tissue damage are not yet fully understood. However, accumulating evidence has implied that the production of free radicals plays a critical role in these processes (Liu et al. 1996, Liu and Mori 1999, Olivenza et al. 2000, Madrigal et al. 2002, Zaidi et al. 2003). Previous studies have indicated that stress stimulated numerous pathways leading to increased levels of free radicals (Liu et al. 1996, Liu and Mori 1999, Olivenza et al. 2000, Liu et al. 1994, Matsumoto et al. 1999). One of the reasons for the stress-induced enhancement of free radicals may be the elevation of nitric oxide (NO) production (Matsumoto et al. 1999, McCann 1997). NO may interact with oxygen, superoxide anion, and thiol compounds, generating reactive nitrogen species $\left(\mathrm{NO}_{\mathrm{x}}\right)$, peroxynitrite $\left(\mathrm{ONOO}^{-}\right)$ and S-nitrosothiols including S-nitrosoglutathione (GSNO). Lipid peroxidative effect of NO may be mediated through $\mathrm{ONOO}^{-}$which is a potent and longlived oxidant (Chiueh and Rauhala 1999, Siu et al. 1999, Rubbo et al. 2000).

Under normal conditions, there is also a natural defense system provided by several enzymes such as superoxide dismutase (SOD), catalase (CAT) and glutathione peroxidase (GSH-Px) which performs a vital role for detoxification of free radicals. However, stress 
has been shown to cause depletion of the glutathionebased antioxidant defense and a decrease in the level of vitamin C (Matsumoto et al. 1999, Zaidi et al. 2003, Zaidi and Banu 2004). The deleterious effects of an imbalance between free radical production and the available antioxidant defence capacity, termed oxidative stress has been implicated in the stress as well as in the pathogenesis of several disease states. One of the important consequences of oxidative stress is the peroxidation of membrane lipids. Since the retina and brain tissues include high content of polyunsaturated fatty acids, this reaction produce marked damage to the structure and function of cell membranes in these tissues (Jain et al. 1991, Matsumoto et al. 1999). Therefore, lipid peroxidation was supposed as the major biochemical alteration underlying oxidant-induced cell injury in stress including numerous diseases (Shaheen et al. 1993, Liu et al. 1994, Olivenza et al. 2000, Zaidi and Banu 2004).

The use of antioxidant rich food or antioxidant food supplements became immensely popular since many diseases have been associated with oxidative stress. Therefore, in the last decade, an increasing amount of attention has been focused on free radical scavengers that are able to protect against aberrant effects of free radicals. Thus, one of the natural molecules known to prevent or retard oxidation is a lipoic acid (LA) and, therefore, the lipoic acid/dihydrolipoic acid (LA/DHLA) redox couple has received considerable attention (Marangon et al. 1999). It is well known that LA is readily absorbed from diet and also crosses the blood-brain barrier (BBB) (Morikawa et al. 2001, Harnett et al. 2001).

Thus, recent studies have highlighted the potential of free LA and DHLA as powerful metabolic antioxidants that are able to scavenge the reactive oxygen species, to recycle other antioxidants (vitamin $\mathrm{C}$, glutathione, and vitamin E). Additionally, LA functions as a cofactor in several mitochondrial multienzyme complexes involved in energy production (Suzuki et al. 1991, Hagen et al. 1999, Marangon et al. 1999, Morikawa et al. 2001). In the present study, the main goal was to investigate the beneficial effects of LA and whether this supplementation could affect antioxidant status and oxidative stress. In this context, thiobarbituric acid reactive substances (TBARS) were measured as an indicator of lipid peroxidation. Additionally, $\mathrm{Cu}, \mathrm{Zn}$ SOD, GSH-Px and CAT activities were evaluated to determine the antioxidant defense system response to chronic restraint stress and to clarify the antioxidative potential of LA. Finally, nitrite/nitrate, stable nitric oxide metabolites, were also determined to evaluate the effect of LA on NO production.

\section{Materials and Methods}

Animals

Twenty four healthy male albino rats, aged three months, were used in this study. They were equally divided into four groups: controls (C), the group treated with LA (L), the group exposed to restraint stress (S), and the group exposed to restraint stress and treated with LA (LS). Animals were housed in a group of 6 rats in stainless steel cages at standard conditions $\left(24 \pm 2{ }^{\circ} \mathrm{C}\right.$ and $50 \pm 5 \%$ humidity) with $12 \mathrm{~h}$ light-dark cycle.

Lipoic acid (LA, Sigma, St. Louis, MO, USA; $100 \mathrm{mg} / \mathrm{kg} /$ day) was injected intraperitonally to the $\mathrm{L}$ and LS groups for 21 days. Physiologic saline was injected intraperitonally to the $\mathrm{C}$ and $\mathrm{S}$ group for 21 days.

\section{Experimental procedures}

All experimental protocols conducted in rats were in accordance with the standards established by the Institutional Animal Care and Use Committee at Akdeniz University Medical School. The experiments were performed between 9:00-12:00.

\section{Restraint stress}

Restraint stress model was performed according to the methods described by Gamoro et al. (1999). Rats were exposed to 1 hour of restraint stress daily for 21 days by placing the animals in a $25 \times 7 \mathrm{~cm}$ plastic bottle. The bottle was fixed with plaster tape on the outside so it was unable to move. There was $1.5 \mathrm{~cm}$ hole at one end of the bottle for breathing. Daily food and water consumption of every cage and weekly body weight of individual rat were recorded during the feeding period. The mean daily food and water consumption was estimated from the recorded values.

\section{Chemical analysis}

After 21 days of the experiment, the rats were sacrificed by exsanguination via cardiac puncture. The isolated retina and brain tissues were placed in $2 \mathrm{ml}$ and $4 \mathrm{ml}$ of $50 \mathrm{mM}$ potassium phosphate buffer, $\mathrm{pH}: 7.4$ at $0-4{ }^{\circ} \mathrm{C}$. All tissues were rapidly sonicated in a thermally regulated sonicator (Branson Sonifier 250, G. Heinemann Ultraschall- und Labortechnik, Schwäbisch Gmünd, Germany) for $1 \mathrm{~min}$. A part of the tissue sonicates was centrifuged at $13000 \mathrm{xg}$ for $10 \mathrm{~min}$ at $4{ }^{\circ} \mathrm{C}$ in an 
Eppendorf microcentrifuge and the supernatants were used for the assay of TBARS nitrite, nitrate and protein. Another part of the samples were centrifuged at $700 \mathrm{x} \mathrm{g}$ for $10 \mathrm{~min}$ and used for the assay of CAT, remaining tissue sonicates were centrifuged at $20000 \mathrm{x}$ g for $60 \mathrm{~min}$ at $0-4{ }^{\circ} \mathrm{C}$ and supernatants were employed for the enzymatic assay of GSH-Px and SOD.

\section{TBARS assay}

TBARS levels were measured by a fluorometric method described by Wasowicz et al. (1993) using 1,1,3,3-tetra-ethoxy-propane as a standard. Tissue samples $(50 \mu \mathrm{l})$ were introduced into a tube containing $29 \mathrm{mmol} / \mathrm{l}$ 2-thiobarbituric acid (TBA), acetic acid $(8.75 \mathrm{M})$ and samples were placed in a water bath and heated for $1 \mathrm{~h}$ at $95-100{ }^{\circ} \mathrm{C}$. After the samples had cooled, $25 \mu \mathrm{l}$ of $5 \mathrm{M} \mathrm{HCl}$ were added and the reaction mixture was extracted by agitation for 5 min with $3.5 \mathrm{ml}$ n-butanol. After centrifugation, the butanol phase was separated and the fluorescence of the butanol extract was measured in a spectrofluorometer (Shimadzu RF-5500, Kyoto, Japan) using wavelengths of $525 \mathrm{~nm}$ for excitation and $547 \mathrm{~nm}$ for emission. The results are given as nmol/g protein.

\section{Assay of SOD activity}

SOD activity was assayed by the method described by Misra and Fridovich (1972). Supernatants were added to reaction mixture $\left(550 \mu 1 \mathrm{HCO}_{3}\right.$ buffer, 400 $\mu \mathrm{l}$ EDTA, $500 \mu \mathrm{l}$ epinephrine) and SOD activity was measured at $480 \mathrm{~nm}$. Adrenochrome was generated with epinephrine autooxidation. Since the production of adrenochrome is inhibited by $\mathrm{Cu} / \mathrm{Zn} \mathrm{SOD}, \mathrm{Cu} / \mathrm{Zn}$ SOD is responsible from the change of absorbance at $480 \mathrm{~nm}$ at which the absorbance of adrenochrome is maximal. SOD activity was expressed as the amount of the SOD standard showing activity equivalent to the determined activity. Data was expressed as U/g protein.

\section{Assay of GSH-Px activity}

GSH-Px activity was measured by the method of Paglia and Valentine (1967). GSH-Px activity was measured indirectly by the coupled reaction with glutathione reductase. Oxidized glutathione (GSSG), produced upon reduction of $t$-butyl hydroperoxide by GPx, is recycled to its reduced state by GR and NADPH. The oxidation of NADPH to NADP ${ }^{+}$is accompanied by a decrease in absorbance at $340 \mathrm{~nm}$ that is measured spectrophotometrically. One unit of GPx activity is defined as the amount of enzyme that will cause the oxidation of $1 \mathrm{~mol}$ of NADPH to $\mathrm{NADP}^{+}$per minute. Data are expressed as U/g protein.

\section{Assay of CAT activity}

Catalase activity was assayed by the method of Aebi (1987), with hydrogen peroxide as the substrate. The final volume of each enzyme assay was $1.5 \mathrm{ml}$ containing $0.5 \mathrm{ml}$ of $30 \mathrm{mM}$ hydrogen peroxide and $1.0 \mathrm{ml}$ supernatant of tissue. Assay was performed at $25{ }^{\circ} \mathrm{C}$ and $240 \mathrm{~nm}$. Enzyme activity was expressed as $\mathrm{k} / \mathrm{g}$ protein $(\mathrm{k}$ : rate constant of the first order reaction as defined by Aebi).

\section{Nitrite assay}

Nitrite levels were measured by a flourometric assay defined by Misko et al. (1993). This assay is based on the reaction of nitrite with an acid form of 2,3-diaminonaphthalene to form the highly fluorescent product 1-(H)-naphthotriazole. $100 \mu \mathrm{l}$ supernatant was mixed with $20 \mu 1$ 2,3-diaminonaphtalene (DAN) in $0.62 \mathrm{M}$ $\mathrm{HCl}$. This mixture was incubated in the dark temperature for $10 \mathrm{~min}$. The reaction was stopped by the addition of $0.28 \mathrm{M} \mathrm{NaOH}$. The fluorescence was measured using Perkin Elmer LS 50B fluorimeter, with the excitation wavelength set at $365 \mathrm{~nm}$ and the emission wavelength set at $450 \mathrm{~nm}$. Nitrite values are expressed as $\mathrm{nmol} / \mathrm{g}$ protein.

\section{Nitrate assay}

Nitrate levels were measured by the method of Bories et al. (1995). Tissue samples (100 $\mu \mathrm{l})$ were introduced into a tube containing $250 \mu \mathrm{l}$ of $100 \mathrm{mmol} / 1$ potassium phosphate buffer ( $\mathrm{pH} 7.5), 50 \mu \mathrm{l}$ of distilled water, $50 \mu \mathrm{l}$ of $0.2 \mathrm{mmol} / \mathrm{l} \mathrm{FAD}$, and $10 \mu \mathrm{l}$ of $12 \mathrm{mmol} / \mathrm{l}$ $\beta$-NADPH. This mixture equilibrated to $25{ }^{\circ} \mathrm{C}$. To start the enzymatic reaction added $40 \mu \mathrm{l}$ of $500 \mathrm{U} / 1$ nitrate reductase, immediately mixed it, and allowed the reaction to develop in the dark because of the photolability of FAD. After $45 \mathrm{~min}$, the absorbance at $340 \mathrm{~nm}$ was recorded by spectrophotometer. Nitrate values are expressed as nmol/g protein.

\section{Determination of proteins}

The amount of protein in the tissues was determined by using the method of Lowry et al. (1951) referring to the albumin as standard.

\section{Statistical analysis}

The statistical software package SPSS 10.0 for 


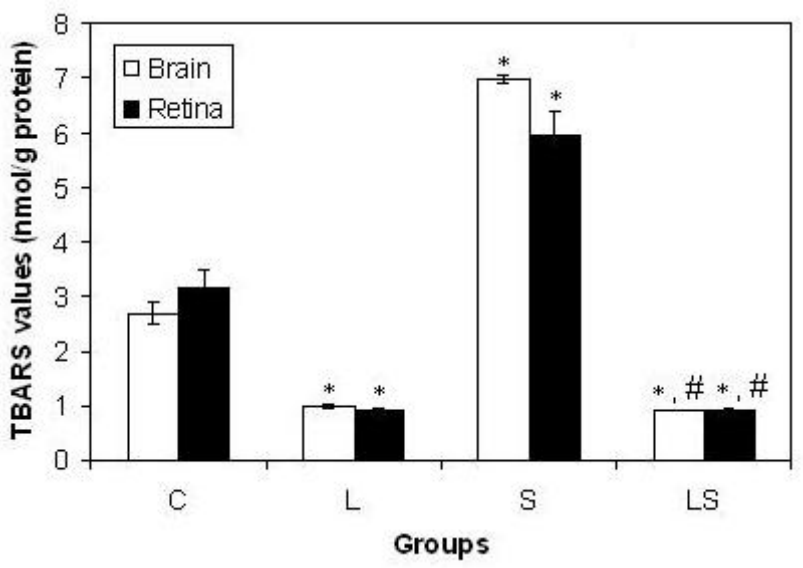

Fig. 1. Thiobarbituric acid reactive substances (TBARS) values of brain and retina tissues were seen in all groups. Values are means \pm standard errors. $*: p<0.01$ versus $C$ group, $\#: p<0.01$ versus $\mathrm{S}$ group. Control (C), Lipoic acid (L), Restraint stress (S), Restraint stress + Lipoic acid (LS).

windows was used to analyse the data. Number of rats was six for all groups studied. Statistical analysis was undertaken by using the non-parametric Mann-Whitney U-test. Differences were considered significant if $\mathrm{p}<0.05$. Results were expressed as means \pm standard errors.

\section{Results}

In the present study, body weight and food intake were not significantly affected by exposure to stress and/or LA.

Brain and retina TBARS levels were significantly increased in the $\mathrm{S}$ group with respect to the control group. LA reduced retina and brain TBARS levels in the $\mathrm{L}$ and LS groups compared with their corresponding control groups (Fig. 1).

Restraint stress significantly decreased brain and retina GSH-Px and CAT activities in comparison with the control group. In the stress condition, $\mathrm{Cu}, \mathrm{Zn}-\mathrm{SOD}$ activity was also decreased in the brain, but not in the retina with respect to the $\mathrm{C}$ group. LA increased brain and retina $\mathrm{Cu}, \mathrm{Zn}-\mathrm{SOD}$ and GSH-Px activities of the L group, whereas it decreased CAT activities of this group compared with the $\mathrm{C}$ group. LA increased all enzyme activities in both brain and retina in the LS group compared with the $\mathrm{S}$ group (Tables 1 and 2).

In the stress group there was a marked increase in the brain and retina nitrite and nitrate levels in comparison with the $\mathrm{C}$ group. LA produced a significant decrease in brain and retina nitrite and nitrate levels of the L and LS groups with respect to their corresponding control groups (Figs 2 and 3).

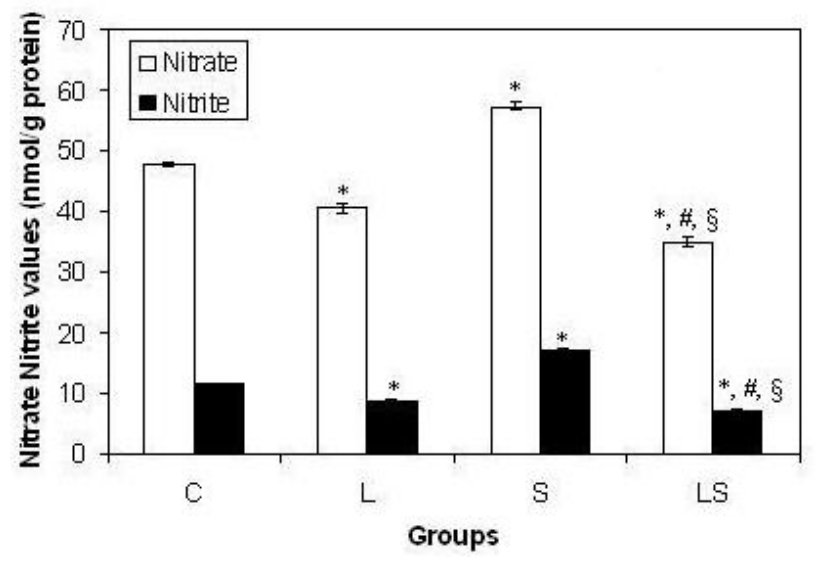

Fig. 2. Nitrate and nitrite values of brain tissues were seen in all groups. Values are means \pm standard errors. $*$ : $p<0.01$ versus $C$ group, \#: $p<0.01$ versus $S$ group, $\S: p<0.01$ versus $L$ group. Control (C), Lipoic acid (L), Restraint stress (S), Restraint stress + Lipoic acid (LS).

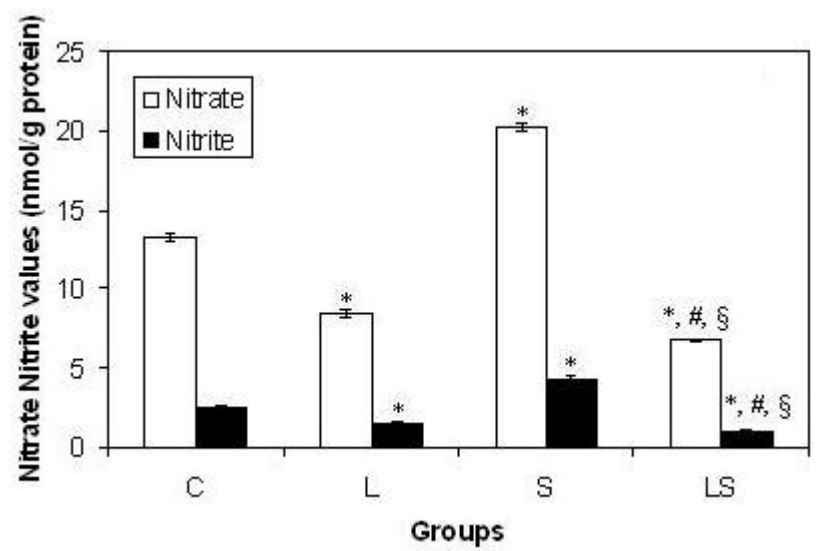

Fig. 3. Nitrate and nitrite values of retina tissues were seen in all groups. Values are means \pm standard errors. *: $p<0.01$ versus $C$ group, \#: $p<0.01$ versus $S$ group, $\S: p<0.01$ versus $L$ group. Control (C), Lipoic acid (L), Restraint stress (S), Restraint stress + Lipoic acid (LS).

\section{Discussion}

The activities of SOD, GSH-Px and catalase were decreased, while the level of TBARS was increased in the stressed rats as compared to the control group. The observed increase in lipid peroxidation in brain and retina, as determined by the measurement of TBARS, are also in agreement with previous studies (Liu et al. 1996, Liu and Mori 1999, Matsumoto et al. 1999, Yargicoglu et al. 2003). Additionally, the present study provides experimental data showing that brain and retina GSH-Px and CAT together brain SOD activities became decreased in the restraint stress. Therefore, in line with the results of earlier reports, it could be suggested that the elevated lipid peroxidation in stress 
Table 1. Superoxide dismutase (SOD), glutathione peroxidase (GSH-Px), and catalase values of brain tissues.

\begin{tabular}{lccc}
\hline Groups & $\begin{array}{c}\text { SOD } \\
\text { (U/g protein) }\end{array}$ & $\begin{array}{c}\text { GSH-Px } \\
\text { (U/g protein) }\end{array}$ & $\begin{array}{c}\text { Catalase } \\
\text { (k/g protein) }\end{array}$ \\
\hline Control $(C)$ & $7.89 \pm 0.36$ & $40.26 \pm 0.96$ & $3.91 \pm 0.24$ \\
Lipoic Acid $(L)$ & $16.51 \pm 4.36$ & $50.44 \pm 0.59$ & $1.86 \pm 0.25$ \\
& $\mathrm{C}^{*}$ & $\mathrm{C}^{* *}$ & $\mathrm{C}^{* *}$ \\
Restraint Stress $(S)$ & $3.68 \pm 0.35$ & $30.45 \pm 0.67$ & $1.50 \pm 0.07$ \\
Restraint Stress + & $\mathrm{C}^{* * *}$ & $\mathrm{C}^{* *}$ & $\mathrm{C}^{* *}$ \\
Lipoic Acid $(L S)$ & $17.63 \pm 2.34$ & $40.35 \pm 1.59$ & $2.17 \pm 0.19$ \\
\end{tabular}

Values are means \pm standard errors. $* p<0.05, * * p<0.01, * * * p<0.001$

Table 2. Superoxide dismutase (SOD), glutathione peroxidase (GSH-Px), and catalase values of retina tissues.

\begin{tabular}{lccc}
\hline Groups & SOD & GSH-Px \\
& (U/g protein) & (U/g protein) & $\begin{array}{c}\text { Catalase } \\
\text { (k/g protein) }\end{array}$ \\
\hline Control $(C)$ & $19.53 \pm 1.62$ & $4.39 \pm 0.07$ & $51.34 \pm 2.43$ \\
Lipoic Acid $(L)$ & $32.95 \pm 2.69$ & $5.18 \pm 0.09$ & $23.27 \pm 1.51$ \\
& $\mathrm{C}^{* *}$ & $\mathrm{C}^{* *}$ & $\mathrm{C}^{* *}$ \\
Restraint Stress $(S)$ & $20.24 \pm 1.44$ & $3.61 \pm 0.10$ & $12.30 \pm 0.82$ \\
Restraint Stress + & $27.31 \pm 1.09$ & $\mathrm{C}^{* *}$ & $\mathrm{C}^{* *}$ \\
Lipoic Acid $(L S)$ & $\mathrm{C}^{*}, \mathrm{~S}^{*}$ & $\mathrm{~L}^{* *}, \mathrm{~S}^{* *}$ & $25.92 \pm 1.36$ \\
\end{tabular}

Values are means \pm standard errors. $* p<0.05, * * p<0.01$

may result from the decreased activities of antioxidant enzymes (Zaidi et al. 2003, Zaidi and Banu 2004).

There have been many reports suggesting that free radicals play an aberrant role in the mechanism of stress (Shaheen et al. 1993, Kovacs et al. 1996, Liu and Mori 1999, Olivenza et al. 2000, Yargicoglu et al. 2003, Yargicoglu et al. 2004). High lipid content in retina and brain is important for the high vulnerability of these tissues to oxidative stress. This is because peroxidative damage of membrane lipids leads to many damages in a cell such as decreases in membrane fluidity, elevated sensitivity to oxidant stress and changes in enzyme activities (Inoue et al. 1993, Kovacs et al. 1996, Liu et al. 1996, Liu and Mori 1999). Therefore, the important consequences of chronic stress could be attributed to stress-induced lipid peroxidation. In this regard, LA was used in the present study since it was recently gained considerable attention as an antioxidant.

The treatment of rats with LA showed an increase in the activities of antioxidant enzymes with a decrease in lipid peroxidation. In accordance with the earlier studies (Scott et al. 1994, Han et al. 1997, Marangon et al. 1999, Hagen et al. 1999, Arivazhagan et al. 2000, Sahin et al. 2006), LA has been observed to be highly effective in protecting stress-induced lipid peroxidation. Moreover, LA treatment of rats resulted in an increase in the activities of SOD, GSH-Px and CAT in the stressed and non-stressed rats with respect to their corresponding groups. From the results obtained, it could be concluded that this compound has an excellent antioxidant activity.

Our data indicated that stress induced a significant inhibition of SOD. The possible reason for this finding could be the decrease of this enzyme caused by enhanced lipid peroxidation under the stress condition (Chaudiere and Ferrari-Iliou 1999). On the other hand, declined SOD activity in brain tissues of stressed rats was brought back to a normal level with administration of LA. This result can be explained by the effect of LA on nerve growth factor (NGF). NGF provides expression of 
superoxide dismutase gene which is a factor leading to increment of SOD (Nistico et al. 1992).

The stress-induced decrease in the activity of GSH-Px documented in our study is corroborated by earlier investigations (Al-Qirim et al. 2002, Yargicoglu et al. 2003, Zaidi and Banu 2004). GSH-Px activity in the retina and brain of stressed rats was also restored to a normal level by the administration of LA. GSH-Px catalyzes the reduction of hydrogen peroxide $\left(\mathrm{H}_{2} \mathrm{O}_{2}\right)$ to $\mathrm{H}_{2} \mathrm{O}$ and $\mathrm{O}_{2}$ at the expense of glutathione (GSH) (Arivazhagan et al. 2000, Devi and Kiran 2004). Therefore, the increment of GSH-Px activity in LA groups indicated that LA increased intracellular glutathione levels. Since GSH has an important role in the protection of vitamin $\mathrm{E}$ and $\mathrm{C}$ levels (Fang et al. 2002), it could be suggested that this effect of LA is one of the important antioxidant properties.

LA increased CAT activities in the brain and retina tissues. The observed decrease in the activity of CAT in stress is consistent with earlier studies (Al-Qirim et al. 2002, Yargicoglu et al. 2003, Zaidi and Banu 2004). The decline in CAT can be attributed to ineffective scavenging of $\mathrm{H}_{2} \mathrm{O}_{2}$ resulting in increased $\mathrm{H}_{2} \mathrm{O}_{2}$ levels, which can react with $\mathrm{O}_{2}{ }^{-}$to give $\mathrm{OH}$ radical and thus increased lipid peroxidation. Catalase requires NADPH for its regeneration from its inactive form (Packer et al. 1997, Arivazhagan et al. 2000). LA is able to increase glucose uptake in vitro (Haugaard and Haugaard 1970). Enhanced glucose uptake by cells serves as a fuel for both the pentose phosphate shunt and oxidative phosphorylation, thus bringing up the cellular levels of NADPH and nicotinamide adenine dinucleotide (NADH) and thereby also enhances the activity of catalase in restraint stress (Arivazhagan et al. 2000).

In the present study, we found that LA contributes to antioxidant defense by increasing CAT activity in the stress group. On the other hand, it was observed that LA significantly decreased levels of brain and retina CAT enzyme in the $\mathrm{L}$ group compared with the control group. The cause of these contradictory data is unclear at present and further research is needed to provide the answer.

One of the reasons for the stress-induced enhancement of free radicals may be the elevation of nitric oxide (NO) production (McCann 1997, Matsumoto et al. 1999). This is further supported by the present determination of nitrite and nitrate levels, which revealed a significant increase in brain and retina NO levels in restrained stressed rats. Previous studies suggested that elevated NO during stress may trigger a lipid peroxidation reaction in the brain and retina, probably due to its conversion to peroxynitrite (McCann et al. 1998, Matsumoto et al. 1999). Peroxynitrite in pure form will cause oxidative damage to protein, lipid, carbohydrate, DNA, subcellular organelles and cell systems (Rubbo et al. 1994). On the other hand, our data on nitrite and nitrate levels in particular experimental groups of the current study clearly showed that LA decreases nitric oxide production (Haramaki et al. 1997, Packer et al. 1997, Harnett et al. 2002). This decrement could be due to direct interactions with $\mathrm{NO}$, to decreased induction of inducible NO synthase, or to increased vitamin $\mathrm{E}$ level. Consequently, LA prevents free radical formation via increasing vitamin $\mathrm{E}$, since vitamin $\mathrm{E}$ has been shown to be an effective antioxidant inhibiting NOinduced lipid peroxidation in rats (Siu et al. 1999, Escames et al. 1997). Therefore, it could be concluded that LA has protective effect against free radical formation thereby preventing the accumulation of toxic NO metabolites. Finally, our present study indicated that 1) chronic stress results in significant alterations in antioxidant enzymes, and 2) LA is an ideal antioxidant candidate for the prevention of stress-induced lipid peroxidation. Because of its ability to act as an antioxidant in fat- and water-soluble tissues in both its oxidized and reduced forms, LA could be used as a potentially effective therapeutic agent in clinical conditions associated with free radical damage.

\section{Conflict of Interest}

There is no conflict of interest.

\section{Acknowledgements}

This study was carried out as part of a MS thesis by Deniz Akpınar presented to Akdeniz University Health Sciences Institute. This research was supported by the Research Fund of Akdeniz University (Grant No: 2002.0122.05).

\section{References}

AEBI H: Catalase of enzymatic analysis. In: Volume III. Enzyme 1: Oxidoreductases, Transferases. BERGMEYER HU (ed), VCH Verlagsggesellschaft, Weinheim, 1987, pp 273-285. 
AL-QIRIM TM, SHAHWAN M, ZAIDI KR, UDDIN Q, BANU N. Effect of khat, its constituents and restraint stress on free radical metabolism of rats. J Ethnopharmacol 83: 245-250, 2002.

ARIVAZHAGAN P, THILAKOVATHY T, PANNEERSELVAM C: Antioxidant lipoate and tissue antioxidants in aged rats. J Nutr Biochem 11: 122-127, 2000.

BORIES PN, BORIES C: Nitrate determination in biological fluids by an enzymatic one-step assay with nitrate reductase. Clin Chem 41: 904-907, 1995.

CHAUDIERE J, FERRARI-ILIOU R: Intracellular antioxidants: from chemical to biochemical mechanisms. Food Chem Toxicol 37: 949-962, 1999.

CHIUEH CC, RAUHALA P: The redox pathway of S-nitrosoglutathione, glutathione and nitric oxide in cell to neuron communications. Free Radic Res 31: 641-650, 1999.

DEVI SA, KIRAN TR: Regional responses in antioxidant system to exercise training and dietary Vitamin E in aging rat brain. Neurobiol Aging 25: 501-508, 2004.

ESCAMES G, GUERRERO JM, REITER RJ, GARCIA JJ, MUNOZ-HOYOS A, ORTIZ GG, OH CS: Melatonin and vitamin E limit nitric oxide-induced lipid peroxidation in rat brain homogenates. Neurosci Lett 230: 147-150, 1997.

FANG YZ, YANG S, WU G: Free radicals, antioxidants, and nutrition. Nutrition 18: 872-879, 2002.

GAMARO GD, MICHALOWSKI MB, CATELLI DH, XAVIER MH, DALMAZ C: Effect of repeated restraint stress on memory in different tasks. Braz J Med Biol Res 32: 341-347, 1999.

HAGEN TM, INGERSOLL RT, LYKKESFELDT J, LIU J, WEHR CM, VINARSKY V, BARTHOLOMEW JC, AMES BN: (R)-alpha-lipoic acid-supplemented old rats have improved mitochondrial function, decreased oxidative damage, and increased metabolic rate. FASEB J 13: 411-418, 1999.

HAN D, HANDELMAN G, MARCOCCI L, SEN CK, ROY S, KOBUCHI H, TRITSCHLER HJ, FLOHE L, PACKER L: Lipoic acid increases de novo synthesis of cellular glutathione by improving cystine utilization. Biofactors 6: $321-338,1997$.

HARAMAKI N, HAN D, HANDELMAN GJ, TRITSCHLER HJ, PACKER L: Cytosolic and mitochondrial systems for NADH- and NADPH-dependent reduction of alpha-lipoic acid. Free Radic Biol Med 22: 535-542, 1997.

HARNETT JJ, AUGUET M, VIOSSAT I, DOLO C, BIGG D, CHABRIER PE: Novel lipoic acid analogues that inhibit nitric oxide synthase. Bioorg Med Chem Lett 12: 1439-1442, 2002.

HAUGAARD N, HAUGAARD ES: Stimulation of glucose utilization by thioctic acid in rat diaphragm incubated in vitro. Biochim Biophys Acta 222: 583-586, 1970.

INOUE T, KOYAMA T, MURAKI A, YAMASHITA I: Effects of single and repeated immobilization stress on corticotropin- releasing factor concentrations in discrete rat brain regions. Prog Neuropsychopharmacol Biol Psychiatry 17: 161-170, 1993.

JAIN A, MARTENSSON J, STOLE E, AULD PA, MEISTER A: Glutathione deficiency leads to mitochondrial damage in the brain. Proc Natl Acad Sci USA 88: 1913-1917, 1991.

KOVÁCS P, JURÁNEK I, STANKOVIČOVÁ T, ŠVEC P: Lipid peroxidation during acute stress. Pharmazie 51: 5153, 1996.

LIU J, MORI A: Stress, aging and brain oxidative damage. Neurochem Res 24: 1479-1497, 1999.

LIU J, WANG X, MORI A: Immobilization stress-induced antioxidant defense changes in rat plasma: effect of treatment with reduced glutathione. Int J Biochem 26: 511-517, 1994.

LIU J, WANG X, SHIGENAGA MK, YEO HC, MORI A, AMES BN: Immobilization stress causes oxidative damage to lipid, protein, and DNA in the brain of rats. FASEB J 10: 1532-1538, 1996.

LOWRY OH, ROSEBROUGH NJ, FARR AL, RANDALL RJ: Protein measurement with Folin phenol reagent. $J$ Biol Chem 193: 265-275, 1951.

MADRIGAL JL, HURTADO O, MORO MA, LIZASOAIN I, LORENZO P, CASTRILLO A, BOSCA L, LEZA J: The increase in TNF- $\alpha$ levels is implicated in NF- $\kappa \mathrm{B}$ activation and inducible nitric oxide synthase expression in brain cortex after immobilization stress. Neuropsychopharmacology 26: 155-163, 2002.

MARANGON K, DEVARAJ S, TIROSH O, PACKER L, JIALAL I: Comparison of the effect of alpha-lipoic acid and alpha-tocopherol supplementation on measures of oxidative stress. Free Radic Biol Med 27: 1114-1121, 1999. 
MASOOD A, BANERJEE B, VIJAYAN VK, RAY A: Modulation of stress-induced neurobehavioral changes by nitric oxide in rats. Eur J Pharmacol 458: 135-139, 2003.

MATSUMOTO K, YOBIMOTO K, HUONG NT, ABDEL-FATTAH M, HIEN TV, WATANABE H: Psychological stress-induced enhancement of lipid peroxidation via nitric oxide systems and its modulation by anxiolytic and anxiogenic drugs in mice. Brain Res 839: 74-84, 1999.

MCCANN SM: The nitric oxide hypothesis of brain aging. Exp Gerentol 32: 431-440, 1997.

MCCANN SM, LICINIO J, WONG ML, YU WH, KARANTH S, RETTORRI V: The nitric oxide synthesis of aging. Exp Gerontol 33: 813-826, 1998.

MISKO TP, SCHILLING RJ, SALVEMINI D, MOORE WM, CURRIE MG: A fluorometric assay for the measurement of nitrite in biological samples. Anal Biochem 214: 11-16, 1993.

MISRA HP, FRIDOVICH I: The role of superoxide anion in the autoxidation of epinephrine and a simple assay for superoxide dismutase. J Biol Chem 247: 3170-3175, 1972.

MORIKAWA T, YASUNO R, WADA H: Do mammalian cells synthesize lipoic acid? Identification of a mouse cDNA encoding a lipoic acid synthase located in mitochondria. FEBS Lett 498: 16-21, 2001.

NISTICO G, CIRIOLO MR, FISKIN K, IANNONE M, DE MARTINO A, ROTILIO G: NGF restores decrease in catalase activity and increases superoxide dismutase and glutathione peroxidase activity in the brain of aged rats. Free Radic Biol Med 12: 177-181, 1992.

OLIVENZA R, MORO MA, LIZASOAIN I, LORENZO P, FERNANDEZ AP, RODRIGO J, BOSCA L, LEZA JC: Chronic stress induces the expression of inducible nitric oxide synthase in rat brain cortex. J Neurochem 74 : 785-791, 2000.

PACKER L, ROY S, SEN CK: Alpha-lipoic acid: a metabolic antioxidant and potential redox modulator of transcription. Adv Pharmacol 38: 79-101, 1997.

PAGLIA DE, VALENTINE WN: Studies on the quantitative and qualitative characterization of erytrocyte glutathione peroxidase. J Lab Clin Med 70: 158-169, 1967.

RUBBO H, RADI R, TRUJILLO M, TELLERI R, KALYANARAMAN B, BARNES S, KIRK M, FREEMAN BA: Nitric oxide regulation of superoxide and peroxynitrite-dependent lipid peroxidation. J Biol Chem 269: 26066$26075,1994$.

RUBBO H, RADI R, ANSELMI D, KIRK M, BARNES S, BUTLER J, EISERICH JP, FREEMAN BA: Nitric oxide reaction with lipid peroxyl radicals spares alpha-tocopherol during lipid peroxidation. Greater oxidant protection from the pair nitric oxide/alpha-tocopherol than alpha-tocopherol/ascorbate. J Biol Chem 275: 10812-10818, 2000.

SAHIN M, SAGDIC G, ELMAS O, AKPINAR D, DERIN N, ASLAN M, AGAR A, ALICIGUZEL Y, YARGICOGLU P: Effect of chronic restraint stress and alpha-lipoic acid on lipid peroxidation and antioxidant enzyme activities in rat peripheral organs. Pharmacol Res 54: 247-252, 2006.

SCOTT BC, ARUOMA OI, EVANS PJ, O’NEILL C, VAN DER VLIET A, CROSS CE, TRITSCHLER HJ, HALLIWELL B: Lipoic and dihydrolipoic acids as antioxidants. A critical evaluation. Free Radic Res 20: 119$133,1994$.

SHAHEEN A, HAMDY MA, KHEIR-ELDIN AA, LINDSTROM P, EL-FATTAH AA: Effect of pretreatment with vitamin E or diazepam on brain metabolism of stressed rats. Biochem Pharmacol 46:194-197, 1993.

SIU AW, REITER RJ, TO CH: Pineal indoleamines and vitamin E reduce nitric oxide-induced lipid peroxidation in rat retinal homogenates. J Pineal Res 27: 122-128, 1999.

SUZUKI YJ, TSUCHIYA M, PACKER L: Thioctic acid and dihydrolipoic acid are novel antioxidants which interact with reactive oxygen species. Free Radic Res Commun 15: 255-263, 1991.

WASOWICZ W, NEVE J, PERETZ A: Optimized steps in fluorometric determination of thiobarbituric acid-reactive substances in serum. Importance of extraction $\mathrm{pH}$ and influence of sample, preservation and storage. Clin Chem 39: 2522-2526, 1993.

YARGICOGLU P, YARAS N, AGAR A, GUMUSLU S, BILMEN S, OZKAYA G: The effect of vitamin E on stressinduced changes in visual evoked potentials (VEPs) in rats exposed to different experimental stress models. Acta Ophthalmol Scand 81: 181-187, 2003. 
YARGICOGLU P, YARAS N, AGAR A, GUMUSLU S, ABIDIN I, BILMEN S: Effects of N-nitro l-arginine methyl ester (1-NAME), a potent nitric oxide synthase inhibitor, on visual evoked potentials of rats exposed to different experimental stress models. Acta Physiol Scand 180: 307-316, 2004.

ZAIDI SM, BANU N: Antioxidant potential of vitamins A, E and C in modulating oxidative stress in rat brain. Clin Chim Acta 340: 229-233, 2004.

ZAIDI SM, AL-QIRIM TM, HODA N, BANU N: Modulation of restraint stress induced oxidative changes in rats by antioxidant vitamins. J Nutr Biochem 14: 633-636, 2003. 